\title{
EXTRACTION AND PURIFICATION OF KANAMYCIN INACTIVATION ENZYME OF ESCHERICHIA COLI K12 ML1629
}

\author{
Yoshio Sakagami, Naoyuki Takaishi and Akira Hachimori \\ Tokyo Institute of Technology, Meguro, Tokyo, Japan \\ (Received for publication January 10, 1973)
}

\begin{abstract}
Kanamycin inactivation enzyme from E. coli K12 ML1629 was partially purified and some properties were examined. The enzyme was very unstable under ultraviolet light, and was stabilized in the presence of -S-S- reductants.
\end{abstract}

Kanamycin resistant Escherichia coli K12 ML1629 carrying R-factor was reported by UMEZAWA, et al. ${ }^{1,2,3)}$ to produce an enzyme which inactivates kanamycin in the presence of ATP and $\mathrm{Mg}^{2+}$. This enzyme is only found in the soluble fraction of broken cells. The enzyme is very unstable and loses the activity rapidly under irradiation of ultraviolet light $(280 \mathrm{~nm})$. It is more stable in the presence of -S-S- reductant. The 3-hydroxyl group of 6-amino-6-deoxy-Dglycose moiety of kanamycin is phosphorylated by the enzyme ${ }^{1,2,3)}$.

In this paper, extraction and purification of kanamycin inactivation enzyme produced by E. coli K12 ML1629 are described.

\section{Materials and Methods}

Strain: E. coli K12 ML1629 was supplied by S. Mitsuhashi, Department of Bacteriology, School of Medicine, Gunma University.

Culture: (1) Still culture. E. coli K12 ML1629 was inoculated in $100 \mathrm{ml}$ of peptone broth (glucose $1 \mathrm{~g}$, peptone $10 \mathrm{~g}, \mathrm{MgSO}_{4} 1.2 \mathrm{~g}, \mathrm{KH}_{2} \mathrm{PO}_{4} 0.44 \mathrm{~g}, \mathrm{CaCl}_{2} 0.1 \mathrm{~g}, \mathrm{NaCl} 3 \mathrm{~g}$ and distilled water $1,000 \mathrm{ml}$, the $\mathrm{pH}$ was adjusted to 7.0 with $1 \mathrm{~N} \mathrm{NaOH}$ ) in 500-ml Erlenmyer's flask and cultured without agitation at $27^{\circ} \mathrm{C}$ for 27 hours. The culture obtained was then added to $900 \mathrm{ml}$ of the same medium which contained kanamycin at $5 \mathrm{mcg} / \mathrm{ml}$ and it was incubated without agitation at $27^{\circ} \mathrm{C}$ for 6 hours. The cells were cellected by centrifugation at $10,000 \times g$ for 9 minutes.

(2) Still culture with aeration: The incubation was carried out in the same way as described above except it was aerated at the rate of $1 \mathrm{ml} / \mathrm{sec}$.

(3) Shaking culture: E. coli K12 ML1629 was inoculated in $100 \mathrm{ml}$ of peptone broth in 500-ml SAKaguchi's flask and incubated at $27^{\circ} \mathrm{C}$ for 27 hours with shaking.

(4) Culture in a jar fermentor: E. coli K12 ML1629 was cultured in the peptone medium by shaking at $27^{\circ} \mathrm{C}$ for 27 hours. One and half liters of cultured broth was inoculated into 13.5 liters of the peptone medium containing kanamycin at $6 \mathrm{mcg} / \mathrm{ml}$ and incubated in a jar fermentor at $27^{\circ} \mathrm{C}$ for 6 hours. The cells were collected by continuous centrifugation.

Assay of enzyme activity: The reaction mixture contained the following materials: $0.7 \mathrm{ml}$ of $50 \mathrm{~mm}$ modified tris- $\mathrm{HCl}$ buffer $\left(\mathrm{KCl} 0.06 \mathrm{M}, \mathrm{MgCl}_{2} \quad 0.01 \mathrm{M}, 2\right.$-mercaptoethanol $0.006 \mathrm{M}$ in $50 \mathrm{~mm}$ tris- $\mathrm{HCl}$ buffer at $\mathrm{pH} 7.8$ ) containing $10 \mu$ moles of disodium ATP and $1.25 \mu$ moles of kanamycin sulfate and $0.3 \mathrm{ml}$ of an enzyme solution. The reaction was carried out at $37^{\circ} \mathrm{C}$ for 3 hours. The reaction mixture was then heated at $80^{\circ} \mathrm{C}$ for 5 minutes and the activity of kanamycin in the reaction mixture was determined by the cylinder method using Bacillus subtilis as the test organism. The enzyme activity was represented by the percentage of kanamycin inactivated.

Determination of protein concentration: The protein concentration in the enzyme solution was determined by the BIURET method ${ }^{4}$ when the concentration was above $1 \mathrm{mg} / \mathrm{ml}$ or the method of LOWRy et al.5), using crystalline bovine serum albumin as the standard, when the concentration was below $1 \mathrm{mg} / \mathrm{ml}$. Also the optical density at $280 \mathrm{~nm}$ was used to determine protein concentration. 
Disc electrophoresis: Polyacrylamide gel electrophoresis was carried out in a tris-glycine buffer $\left(\mathrm{pH} 8.5\right.$ ) according to the procedure of DAVIs ${ }^{6}$. The electrophoresis was carried out at $4^{\circ} \mathrm{C}$ for 50 minutes at $5 \mathrm{~mA} / \mathrm{cm}^{2}$ and protein was stained with Amidoblack $10 \mathrm{~B}$.

\section{Results}

\section{(1) Production of Enzyme}

The production of enzyme was examined using four kinds of fermentation methods. The weight of the wet cells and the enzyme activity of S-100 were determined adjusting the protein concentration of each S-100 to $10 \mathrm{mg} / \mathrm{ml}$. As shown in Table 1, the culture using a jar fermentor gave the best enzyme yield, so that E. coli K12 ML1629 for all experiments were cultured in a jar fermentor.

Table 1. Production of the enzyme

\begin{tabular}{l|c|c}
\hline \multicolumn{1}{c|}{ Method of culture } & $\begin{array}{c}\text { Weight of wetting cell } \\
(\mathrm{g} / \text { liter })\end{array}$ & $\begin{array}{c}\text { Enzyme activity } \\
(\%)\end{array}$ \\
\cline { 2 - 3 } Still culture & 0.22 & 55.0 \\
Still culture with aeration & 1.59 & 52.5 \\
Shaking culture & 2.80 & 57.5 \\
Culture by a jar fermentor & 3.37 & 57.5 \\
\hline
\end{tabular}

(2) Purificarion of Enzyme

All the procedures for purification were conducted at $5^{\circ} \mathrm{C}$ in a darkened room to shut out the ultraviolet light.

Step I. Extraction of enzyme. The cells were washed three or four times with $50 \mathrm{~mm}$ modified tris- $\mathrm{HCl}$ buffer by centrifugation, suspended in the same buffer in a volume equal to the cell pellet and disrupted by passage through a French pressure cell $\left(1,500 \mathrm{~kg} / \mathrm{cm}^{2}\right)$. The suspension of disrupted cells was centrifuged at $100,000 \times \mathrm{g}$ for 90 minutes. More than $97.5 \%$ of the enzyme activity was found in the supernatant. The crude enzyme solution thus obtained was designated $100,000 \times g$ supernatant (S-100).

Step II. Fractionation with ammonium sulfate. The S-100 was fractionated by precipitating with ammonium sulfate. The fraction with high enzyme activity was recovered in $0.38 \sim 0.50$ ammonium sulfate and $0.63 \sim 0.76$ ammonium sulfate saturation. The former fraction was lyophilized for further purification.

Step III. Gel filtration through Sephadex G-200. One g of the lyophilized enzyme was dissolved in $3 \mathrm{ml}$ of $50 \mathrm{~mm}$ modified tris- $\mathrm{HCl}$ buffer. It was applied on a Sephadex G-200 column $(2.7 \times 60 \mathrm{~cm})$ which was previously equilibrated with the same buffer, and eluted with $50 \mathrm{~mm}$ modified tris-HCl buffer. The elution pattern is shown in Fig. 1A.

Step IV. DEAE-Sephadex A-25 column chromatography. The active franctions from gel filtration through Sephadex G-200 were collected and concentrated to $5 \mathrm{ml}$ by collodion dialysis. The concentrate was then applied to a DEAE-Sephadex A-25 column $(1.2 \times 6 \mathrm{~cm})$ which was previously equilibrated with tris- $\mathrm{HCl}$ buffer $(50 \mathrm{~mm}$ at $\mathrm{pH} 7.8)$. The enzyme was eluted stepwise by increasing the cocentration of $\mathrm{KCl}$. The elution pattern is shown in Fig. 1B.

As shown in Table 2, the enzyme was purified 1,170-fold at the final step. However, the enzyme protein was not homogenous as judged by polyacrylamide gel disc electrophoresis. 
Fig. 1. Elution patterns of kanamycin-inactivation enzyme.

A. Gel filtration through Sephadex G-200.

Column: $2.7 \mathrm{~cm} \times 60 \mathrm{~cm}$. Flow rate: $10 \mathrm{ml} /$ hour. Each fraction: $5 \mathrm{ml}$.

B. DEAE-Sephadex A-25 column chromatography.

Column: $1.2 \mathrm{~cm} \times 6 \mathrm{~cm}$. Flow rate: $100 \mathrm{ml} /$ hour. Each fraction: $5 \mathrm{ml}$.
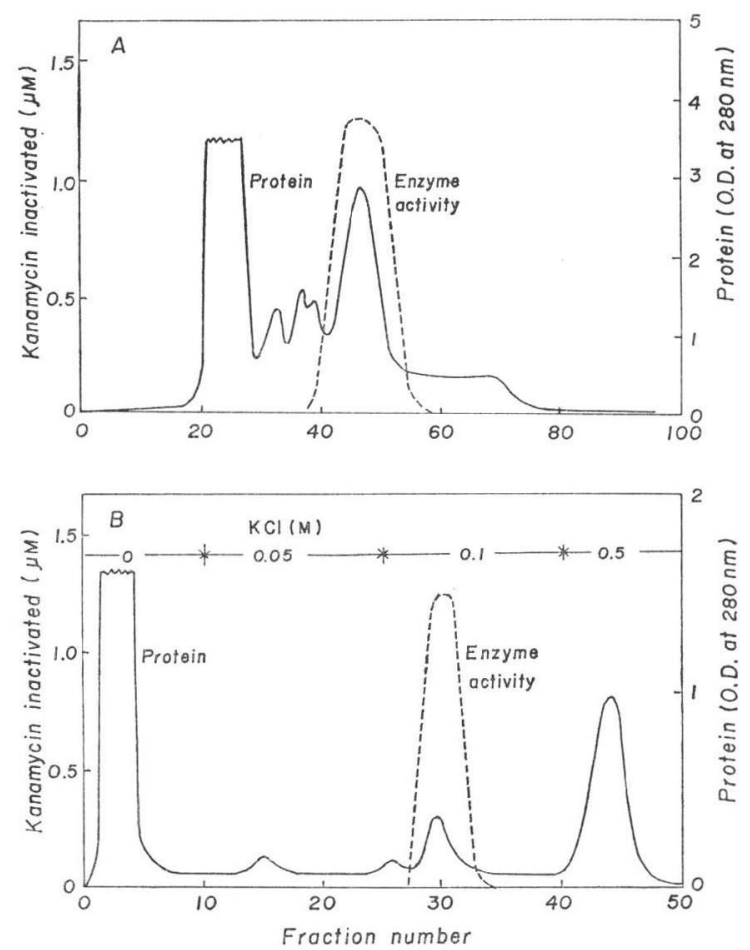

Table 2. Purification of kanamycin inactivation enzyme from E. coli K12 ML1629.

\begin{tabular}{l|r|r|r}
\multicolumn{1}{c|}{ Enzyme fraction } & Specific activity* & Relative increase & Yield $(\%)$ \\
\cline { 2 - 3 } $100,000 \times g$ supernatant (S-100) & $2.67 \times 10^{-3}$ & 1 & 100 \\
$0.38 \sim 0.50\left(\mathrm{NH}_{4}\right)_{2} \mathrm{SO}_{4}$ fraction & $6.69 \times 10^{-3}$ & 2.5 & 31.3 \\
Sephadex G-200 & $93.75 \times 10^{-3}$ & 35.1 & 11.3 \\
DEAE-Sephadex A-25 & $3,125.00 \times 10^{-3}$ & $1,170.4$ & 2.4 \\
\hline
\end{tabular}

* $\mu$ moles of inactivated kanamycin per mg protein per hour.

(3) Purification of Enzyme by Disc Electrophoresis

After the electrophoresis of the active fraction of DEAE-Sephadex A-25, the gel was divided in 5-mm thickness and the activity of the enzyme for each fraction was determined. After the first electrophoresis, $62.5 \%$ of the enzyme activity was shown in the $20 \sim 25 \mathrm{~mm}$ fraction. The active fraction was then put on a new gel and a second electrophoresis was done. The gel was divided into 4-mm fractions and the activity was determined. In the $20 \sim 24 \mathrm{~mm}$ fraction, 59.5\% of the enzyme activity was found. A third electrophoresis was done under the same conditions, and $32 \%$ of the enzyme activity was found in the $30 \sim 35 \mathrm{~mm}$ fraction. When stained with Amidoblack $10 \mathrm{~B}$, the gel of the third electrophoresis was found to have only a single band of protein as shown in Fig. 2. Furthermore, this protein band did not separate by the fourth electrophoresis. 
Fig. 2. Procedure of disc electrophoresis.

The experimental conditions are described in Materials and Methods. The protein used for the first step was $100 \mu \mathrm{g}$.
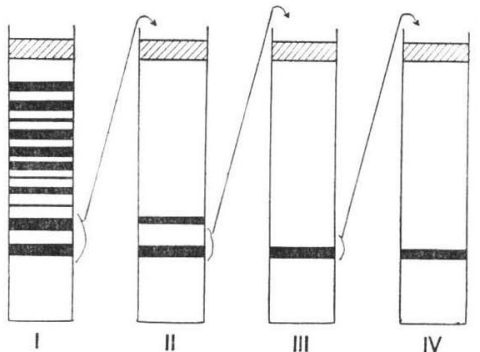

(4) Stability of Enzyme at

Each Step of Purification

(a) Effect of temperature: The stability of the enzyme was examined at $5^{\circ} \mathrm{C}$ and $20^{\circ} \mathrm{C}$ at each step of purification. As shown in Fig. 3, only $9.5 \%$ of activity remained at $20^{\circ} \mathrm{C}$ after 24 hours and the activity was lost completely after 30 hours. However, the activity was unchanged for 48 hours at $5{ }^{\circ} \mathrm{C}$ and decreased to $58.9 \%$ after 72 hours and $36.1 \%$ after 6 days.

The enzyme activity of the ammonium sulfate fraction decreased rapidly and no activity was found after 30 hours at $20^{\circ} \mathrm{C}$. On the other hand, the activity was maintained to a degree of $80 \%$ after 4 days at $5^{\circ} \mathrm{C}$, and lost completely after 6 days. The enzyme activity of the ammonium sulfate fraction in a frozen state began to decrease after 9 days and 55\% of activity remained after 16 days. However, the activity of this fraction after lyophilization was retained to a degree of $97.5 \%$ after 30 days as shown in Fig. 3. Thus, the enzyme can be stored as a lyophilized preparation.

The activity of fractions from Sephadex G-200 and DEAE-Sephadex A-25 was lost rapidly by either freezing or lyophilization, after an hour at $20^{\circ} \mathrm{C}$ or a day at $5^{\circ} \mathrm{C}$. The estimation of the enzyme activity of these fractions was therefore made immediately after the chromatography.

(b) Effect of protein concentration: The effect of protein concentration on the stability of enzyme was examined using the ammonium sulfate fraction. Results in Fig. 4 indicate that the activity of enzyme is progressively lost in smaller concentrations of protein.

(c) Effect of -S-S- reductant and oxidant: The effects of glutathione (oxidized form) (GLT) as a -S-S- oxidant and dithiothreitol (DTT) as a reductant on the stability of the enzyme of

Fig. 3. Effect of temperature on the stability of the enzyme.

Protein concentrations: crude enzyme, $10 \mathrm{mg} /$ $\mathrm{ml}$; ammonium sulfate fraction, $3 \mathrm{mg} / \mathrm{ml}$.

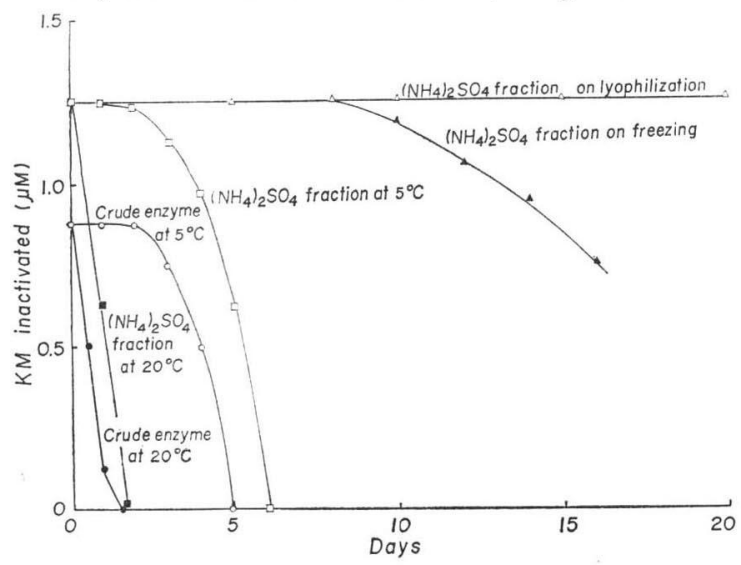

Fig. 4. Effect of protein concentration on the stability of the enzyme.

Ammonium sulfate fraction: $0.38 \sim 0.50$ saturation.

Protein concentration for the reaction: $3 \mathrm{mg} / \mathrm{ml}$.

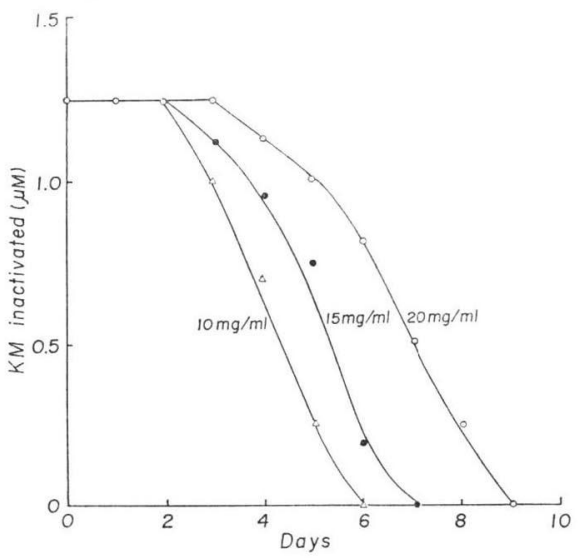


ammonium sulfate fraction were examined. As shown in Fig. 5, the enzyme activity was more unstable with the oxidant than the control. On the other hand, the enzyme was stable in the presence of the reductant, and more than $97.5 \%$ of activity remained after 6 days at $5^{\circ} \mathrm{C}$. Therefore, the effect of other -S-S- reductants such as 2-mercaptoethanol (ME) and thioglycolic acid (TGA) were examined. As a result, the best reagent was found to be DTT at a concentration of $6 \mathrm{~mm}$. DTT can also stabilize the enzyme from Sephadex G-200 and the DEAESephadex A-25 fractions. The reactivation of enzyme with ME, TGA and DTT were examined. After the enzyme activity in a solution containing at $3 \mathrm{~mm}$ of TGA was decreased to $7 \%$ of the original, the concentration of TGA was increased to $9 \mathrm{~mm}$ and the solution was left for two hours. It was found that the enzyme activity recovered to $78 \%$. The results shown in

Fig. 5. Effect of -S-S- reductants and oxidants on the stability of the enzyme.

Ammonium sulfate fraction: $0.38 \sim 0.50$ saturation.

Protein concentration for the reaction: $3 \mathrm{mg}$ $\mathrm{ml}$.

Final concentrations of reagents: $6 \mathrm{~mm}$

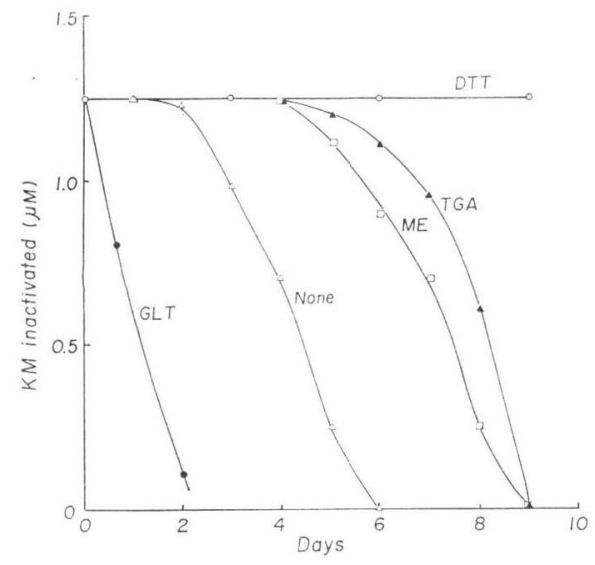

Fig. 6. Reactivation of enzyme with - S-S- reductants.

The experimental conditions: same as Fig. 4. Arrows indicate the addition of reagents.

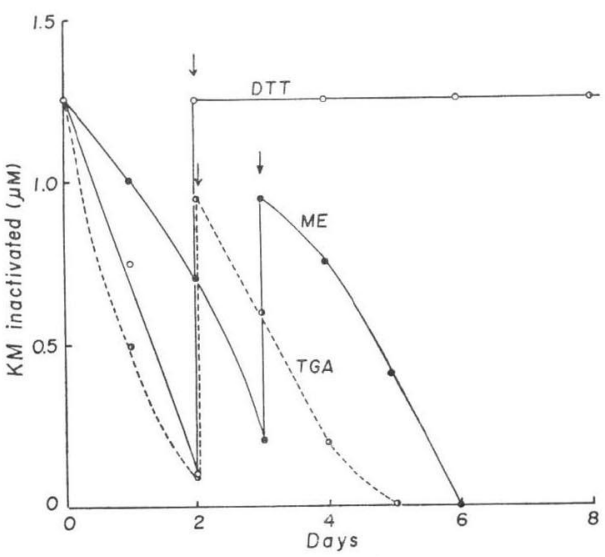

Fig. 6 indicate that $-\mathrm{S}-\mathrm{S}$ - reductants have the ability to reactivate the enzyme activity.

(d) Effect of ultraviolet irradiation: From the result in Fig. 7, it can be noted that the enzyme activity decreased rapidly after ultraviolet irradiation at $280 \mathrm{~nm}$ for 15 minutes. The activity remained 29\% after 60 minutes Therefore, all experiments were done in a darkened room.

(5) Effect of Inhibitors on Enzyme Activity

As the enzyme from DEAE-Sephadex A25 is unstable, the inhibitory effect was examined immediately after the chromatography in the presence of $6 \mathrm{~mm} \mathrm{ME}$. As shown in Table 3, the enzyme activity was inhibited strongly by many inhibitors except adenine and AMP which are both related to ATP.

Fig. 7. Effect of ultraviolet irradiation on the stability of the enzyme.

Protein concentration of $0.38 \sim 0.50$ ammonium sulfate fraction: $3 \mathrm{mg} / \mathrm{ml}$.

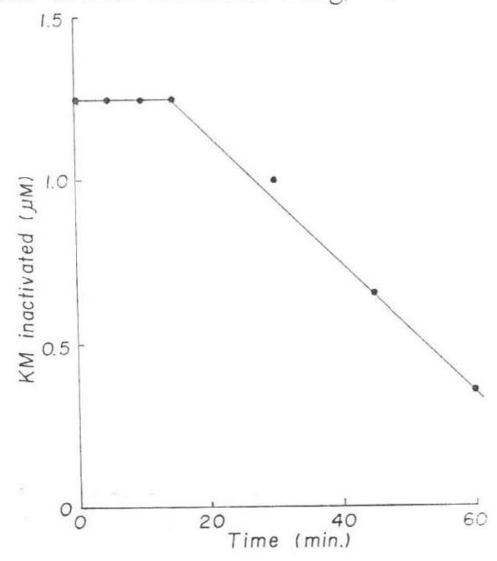


Table 3. Effect of inhibitors on the enzyme activity.

\begin{tabular}{l|c|c}
\hline \multicolumn{1}{c|}{ Inhibitor } & Concentration & $\begin{array}{c}\text { Activity } \\
(\%)\end{array}$ \\
\cline { 2 - 3 } None & $10 \mu \mathrm{M}$ & 97.5 \\
$2,4-\mathrm{Dinitrophenol}_{2}$ & $10 \mu \mathrm{M}$ & 2.0 \\
$\mathrm{Na}_{2} \mathrm{SO}_{3}$ & $10 \mu \mathrm{M}$ & 2.0 \\
$\mathrm{I}_{2}$ & $10 \mu \mathrm{M}$ & 2.0 \\
$\mathrm{NaCN}$ & $10 \mu \mathrm{M}$ & 2.0 \\
EDTA & $10 \mu \mathrm{M}$ & 2.0 \\
ADP & $10 \mu \mathrm{M}$ & 72.5 \\
AMP & $10 \mu \mathrm{M}$ & 68.5 \\
Adenine & $10 \mu \mathrm{M}$ & 2.0 \\
Inorganic phosphate & $10 \%$ & 2.0 \\
Methanol & $10 \%$ & 2.0 \\
Acetone & $10 \%$ & 2.0 \\
Oleinic acid &
\end{tabular}

Fig. 8. Effect of temperature of the reactivity of enzyme.

The experimental conditons: same as Table 3.

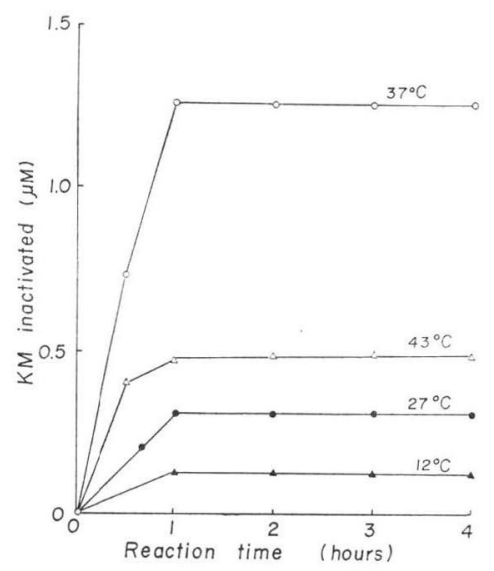

(6) Effect of Temperature on the Reactivity of Enzyme

The reactivity of the enzyme from the DEAE-Sephadex A-25 was the greatest at $37^{\circ} \mathrm{C}$ as shown in Fig. 8. The reaction of the enzyme with kanamycin was complete within an hour at any temperature.

\section{Acknowledgment}

We wish to express our gratitude to Dr. M. OkAnishi (National Institute of Health, Japan) for his advise throughout the course of this work. We wish to thank to Dr, S. MrtsuHAsHi (Gunma University) for supply of strain.

\section{References}

1) Umezawa, H.; M. Okanishi, S. Kondo, K. Hamana, R. Utahara, K. Maeda \& S. Mitsuhashi: Phosphorylative inactivation of aminoglycosidic antibiotics by $E$. coli carrying $\mathrm{R}$ factor. Science 157: $1559 \sim 1561,1967$

2) Okanishi, M.; S. Kondo, R. Utahara \& H. Umezawa: Phosphorylation and inactivation of aminoglycosidic antibiotics by E. coli. carrying R factor. J. Antibiotics 21:13 21, 1968

3) Kondo, S.; M. Okanishi, R. Utahara, K. Maeda \& H. Umezawa: Isolation of kanamycin and paromamine inactivated by $E$. coli. carrying $\mathrm{R}$ factor. J. Antibiotics 21:22 29, 1968

4) Gornall, A. G.; C. J. Bardwill \& M.M. David: Determination of serum proteins by means of the Biuret method. J. Biol. Chem. 177:751 761, 1949

5) Lowry, O. H.; N. J. Rosebrough, A. C. FArR \& R. S. Randoll: Protein measurement with the Folin phenol reagent. J. Biol. Chem. 193:265 275, 1951

6) Davis, B. J.; Disc electrophoresis II. Method and application to human serum proteins. Ann. New York Acad. Sci. 121:404 413, 1964 